\title{
Circulating Cell-Free DNA or Circulating Tumor DNA in the Management of Ovarian and Endometrial Cancer
}

This article was published in the following Dove Press journal: OncoTargets and Therapy

\section{Qian Chen \\ Zi-Han Zhang \\ Shu Wang \\ Jing-He Lang}

Department of Gynecology and Obstetrics, Peking Union Medical College Hospital, Chinese Academy of Medical Sciences and Peking Union Medical College, Beijing, People's Republic of China
Correspondence: Shu Wang; Jing-He Lang Department of Gynecology and Obstetrics, Peking Union Medical College Hospital, Chinese Academy of Medical Sciences and Peking Union Medical College, I

Shuaifuyuan, Wangfujing, DongCheng District, Beijing 100730, People's Republic of China

Tel +86-|0-69|56204

Fax+86-10-69154875

Email wangshu219@hotmail.com; jinghe_l@sina.com

\begin{abstract}
Ovarian cancer (OC) is the most lethal cancer of all gynecological malignancies, while endometrial cancer (EC) is the most common one. Current strategies for OC/EC diagnosis consist of the extraction of a solid tissue from the affected area. This sample enables the study of specific biomarkers and the genetic nature of the tumor. However, the tissue extraction is risky and painful for the patient and in some cases is unavailable in inaccessible tumors. Moreover, a tissue biopsy is expensive and requires a highly skilled gynecological surgery to pinpoint accurately which cannot be applied repeatedly. New alternatives that overcome these drawbacks are rising up nowadays, such as liquid biopsy. A liquid biopsy is the analysis of biomarkers in a non-solid biological tissue, mainly blood, which has remarkable advantages over the traditional method. The most studied cancer non-invasive biomarkers are circulating tumor cells (CTCs), circulating tumor DNA (ctDNA), and circulating free DNA (cfDNA). These circulating biomarkers play a key role in the understanding of metastasis and tumorigenesis, which could provide a better insight into the evolution of the tumor dynamics during treatment and disease progression. Liquid biopsy is an emerging non-invasive, safe and effective method with considerable potential for clinical diagnosis and treatment management in patients with OC and EC. Analysis of cfDNA and ctDNA will provide a better characterization of biomarkers and give rise to a wide range of clinical applications, such as early detection of $\mathrm{OC} / \mathrm{EC}$, the prediction of treatment responses due to the discovery of personalized tumor-related biomarkers, and therapeutic response monitoring.
\end{abstract}

Keywords: ovarian cancer, endometrial cancer, liquid biopsy, circulating cell-free DNA, circulating tumor DNA

\section{Introduction}

In recent years, the continuous development in genomic detection and analysis technology has revealed a more complicated molecular picture of cancers. Such complexity may be caused by the inter/intra-tumoral heterogeneity and clonal evolution, which brings forward a higher demand on a precise and real-time monitoring system. ${ }^{1}$

Ovarian cancer (OC), endometrial cancer (EC) and cervical cancer (CC) are the three major cancers in gynecology. Established screening projects and the prevalence of vaccination have remarkably reduced the incidence and mortality of invasive $\mathrm{CC},{ }^{2}$ but the situation of $\mathrm{OC}$ and $\mathrm{EC}$ is still not optimistic.

Ovarian cancer is an aggressive disease with a high mortality rate, largely due to a lack of effective screening methods or biomarkers with high sensitivity and specificity. ${ }^{3}$ 
A recent review on the benefits and harms of $\mathrm{OC}$ screening among average-risk women included 4 randomized clinical trials involving transvaginal ultrasound (TVS), cancer antigen 125 (CA125) testing, or their combination. The review illustrated no significant difference on mortality between screened women and non-screened or irregular-screened ones. ${ }^{4}$ Furthermore, although the response rate of initial treatment is satisfactory, recurrence rate in advanced-stage OC patients remain high, partly because of insufficient understanding of drug resistance mechanisms. ${ }^{5}$ As a widely used biomarker during the treatment and the follow-up, CA125 does not perform well in clinical work. ${ }^{6}$

Endometrial cancer is the most common cancer occurring in female reproductive tract. ${ }^{7}$ It can be diagnosed and treated at an early stage, due to its typical symptom of abnormal genital bleeding and the subsequent detailed examination. However, some patients present nonspecific symptoms and those with intermediate to high-risk factors are still very vulnerable to recurrence, resulting in a higher mortality rate. The sensitivity and specificity of TVS is too limited to be a screening method for EC, which can only provide a rough evaluation. ${ }^{8}$ Diagnostic dilatation and curettage is effective with high sensitivity and specificity for postmenopausal women, ${ }^{9}$ while the invasive process and possible complications may reduce the compliance of patients. More importantly, it could not be used in the treatment surveillance once the uterus is removed.

Histopathology examination has long been regarded as the gold standard for the final diagnosis and genotypic analysis of OC and EC. However, tissue biopsy is incompatible for clinical longitudinal monitoring due to its invasive nature.

Based on the above, a new strategy for these two types of gynecological malignancies is urgently needed. As a non-invasive and cost-effective method, liquid biopsy is expected to overcome the above shortcomings and has become a research hotspot. ${ }^{10}$ Circulating tumor cells (CTCs), circulating tumor DNA (ctDNA), circulating free RNAs, tumor-derived extracellular vesicles (TEVs) and tumor-educated platelets (TEPs) are the main components released by tumors from either primary or metastatic sites that can be used in a variety of analysis. ${ }^{11}$ In 2017, Cheng et al briefly reviewed the role of circulating cell-free DNA (cfDNA) and CTC in OC, ${ }^{12}$ providing us with important information. In our review, we will focus on the potential value of cfDNA/ ctDNA in $\mathrm{OC}$ and $\mathrm{EC}$ patients.

\section{Origin and Detection of cfDNA/ ctDNA}

It took about 30 years from the first discovery of cfDNA in the blood of healthy people ${ }^{13}$ to the report of its relationship with cancer in $1977 .{ }^{14}$ Researchers found that higher levels of cfDNA appeared in cancer patients and those with metastatic disease compared to the healthy and nonmetastatic ones, respectively. It was not until 1994 that somatic point mutations were identified in cfDNA. ${ }^{15}$ Since then, more studies have focused on this circulating molecular, especially its potential role in cancer management.

A great proportion of cfDNA comes from normal cells of the body, a small part of which is related to tumors, coming from primary tumors, metastatic sites or CTCs, and is called ctDNA. The mechanism of cfDNA being released by cells into circulation was still not fully understood. Mouliere et $\mathrm{al}^{16}$ investigated the sources of circulating DNA of three distinctive categories (normal extratumoral cells, tumor microenvironment cells and neoplastic tumor cells) in colorectal cancer patients, elucidating three sources of cfDNA: necrosis, apoptosis and active secretion. Apoptosis has been reported to be one of the sources of cfDNA, as cfDNA fragments are found to be similar in size to apoptotic DNA. Necrosis might be an important contributor to long cfDNA fragments (over 1000bp). ${ }^{17}$ Another hypothesis of cfDNA release was active secretion, with DNA included in the exosomes or DNA-lipoprotein complexes. ${ }^{16}$

Analysis of ctDNA paves us the way for a comprehensive view of the tumor genomic landscape. The ctDNA fragments ( 134-144 bp) were reported to be shorter than that of cfDNA $(\sim 166 \mathrm{bp}) .{ }^{18,19}$ The proportion of ctDNA in the total cfDNA may vary greatly in accordance with clinicalpathologic features of tumor as well as the tumor microenvironment. ${ }^{20,21}$ Relatively low ctDNA levels in standard blood samples and background cfDNA unrelated to tumor cells make detection a challenge. Therefore, the standard procedure for blood collection and DNA isolation should be finalized prior to analysis..$^{22,23}$

\section{Methodologies in Exploring cfDNA/ ctDNA}

For blood collection, the ratio of plasma germline cfDNA is lower than that of serum; thus, it is more suitable for ctDNA isolation. ${ }^{24}$ Plasma separation should be performed within a short time since the half-time of ctDNA is only about $2 \mathrm{hrs}$ in standard EDTA tubes. ${ }^{25}$ Some other special blood 
collection tubes with special preservatives, such as Streck, allow for delayed plasma separation. ${ }^{26}$ After centrifugation, the separated plasma should be stored at $-80^{\circ} \mathrm{C}$ for later use.

The extraction of cfDNA/ctDNA is the key to the subsequent test. Available methods include phase isolation, silicon membrane-based spin column, and magnetic bead-based isolation. ${ }^{27}$ The extraction efficiency varies depending on the methods and the plasma volumes. ${ }^{28}$

New techniques have emerged with high sensitivity and high specificity for the analysis of cfDNA or ctDNA from a quantitative and qualitative perspective, ${ }^{29-31}$ such as polymerase chain reaction (PCR) strategies and NextGeneration Sequencing (NGS) strategies.

There is a variety of PCR-based methods, each with its characteristics, including real-time PCR, co-amplification at lower denaturation temperature-PCR, methylation-specific PCR, digital PCR or droplet digital PCR (ddPCR), "Beads, Emulsion, Amplification, Magnetics digital PCR" (BEAMing) and so on. ${ }^{24}$ Designed to detect hotspot mutations, these PCRbased methods are relatively time-saving and economical.

Next-Generation Sequencing (NGS)-based methods such as tagged-amplicon deep sequencing (TamSeq), the Safe Sequencing System (SafeSeqS), CAncer Personalized Profiling by deep Sequencing (CAPP-Seq) and targeted error correction sequencing (TEC-Seq) are available to assess genetic alterations with different detection capacities. ${ }^{24}$ Whole Genome Sequencing (WGS) and Whole Exome Sequencing (WES) technologies allow for the identification of novel alterations with no pre-existing knowledge. ${ }^{32,33}$ The ability of NGS-based methods to detect copy number variations (CNVs) is an advantage over PCR. ${ }^{24}$ Though efficient, these methods are relatively time-consuming and require professional bioinformatics analysis.

\section{Application of cfDNA/ctDNA in Ovarian and Endometrial Cancer}

As a promising effective tool in oncology, cfDNA/ctDNA is of essential value in clinical management of ovarian and endometrial cancer patients from the diagnostic, predictive and prognostic aspects (Table 1; Figure 1).

\section{Early Detection and Differential Diagnosis}

As previously mentioned, the diagnostic value of blood markers and imaging examinations for early detection and differential diagnosis of ovarian and endometrial tumors is limited. Plenty of studies have been carried out to evaluate the competency of cfDNA/ctDNA in cancer screening.

\section{Quantification of cfDNA/ctDNA Ovarian Cancer}

Changes in levels of cfDNA/ctDNA can be a hint for the existence of malignance, which could be more accurate than CA125 or HE4 in some OC studies. Shao et al reported a significant increment of cfDNA levels in the OC group compared with the control group $(\mathrm{P}<0.01)$. They also noticed a higher sensitivity and specificity $(88.9 \%$ and $89.5 \%)$ of cfDNA than CA125 (75\% and 52.6\%) and HE4 $(80.6 \%$ and $68.4 \%)$ in OC detection. Sensitivity and specificity were promoted $(91.67 \%$ and $84.21 \%)$ when the above biomarkers were combined. ${ }^{34}$ Similarly, a cohort study of OC achieved a sensitivity and specificity of $87-91.5 \%$ and $85-87 \%$, respectively. By comparison, they found a lower false-positive rate of cfDNA level than CA125. ${ }^{35}$ Another small sample study focusing on three endogenous loci ( $G A P D H, \beta$-actin and $\beta$-globin) identified significantly higher cfDNA levels among OC patients compared to controls, with the greatest difference occurring at $\beta$-actin locus. ${ }^{36}$ Quantitative alterations of circulating cell-free nuclear DNA and circulating cellfree mitochondrial DNA were evaluated to confirm their values in diagnosing $\mathrm{OC}$ with moderate sensitivity and specificity. ${ }^{37}$ Dobrzycka et al found that the detection rate of ovarian serous carcinoma was higher than other types, suggesting the role of cfDNA in differential diagnosis. $^{38}$

\section{Endometrial Cancer}

The role of cfDNA levels for EC screening and classification appears to be controversial. Significantly elevated total cfDNA levels were detected in EC group compared with the controls, with higher levels in high-grade groups (G2 and G3). ${ }^{39}$ Another study reported a dramatic difference between the mean level of cfDNA in patients with type I and type II EC. ${ }^{40}$ Vizza et al observed a remarkably increased total cfDNA content in high-grade EC patients. They adopted a special calculation method applying Aluquantitative real-time PCR (qPCR) technology to investigate the role of cfDNA. The serum DNA integrity index, defined as qPCR-Alu247 value/qPCR-Alu115 value of each sample, was significantly reduced in high-grade EC patients with hypertension and obesity. Unfortunately, this index presented a low predictive accuracy to differentiate high grade from low-grade EC patients. ${ }^{41}$ The study carried out by Tanaka et al showed no significant difference of cfDNA levels between EC and the controls, partly due to the small sample size or differences in methods. ${ }^{42}$ 
Table I Studies with Analysis of cfDNA/ctDNA in OC or EC Patients

\begin{tabular}{|c|c|c|c|c|c|c|c|}
\hline References & Country & $\begin{array}{l}\text { Cancer } \\
\text { Type }\end{array}$ & Sources & $\begin{array}{l}\text { Cancerl } \\
\text { Control }\end{array}$ & Abnormalities & Methodology & $\begin{array}{l}\text { Clinical } \\
\text { Relevance }\end{array}$ \\
\hline Shao et $\mathrm{al}^{34}$ & China & OC & Serum & $36 / 41$ & Level & $\begin{array}{l}\text { bDNA } \\
\text { technique }\end{array}$ & Diagnosis \\
\hline Kamat et $\mathrm{al}^{35}$ & USA & OC & Plasma & $164 / 124$ & Level & RT-PCR & Diagnosis \\
\hline Kamat et $\mathrm{al}^{36}$ & USA & OC & Plasma & $19 / 12$ & Level & RT-PCR & Diagnosis \\
\hline Zachariah et $\mathrm{al}^{37}$ & Switzerland & OC & Serum/plasma & $21 / 83$ & Level & RT-PCR & Diagnosis \\
\hline Dobrzycka et al ${ }^{38}$ & Poland & OC & Plasma & I26/NA & Level/KRAS mutation & PCR-RFLP & $\begin{array}{l}\text { Diagnosis/ } \\
\text { prognosis }\end{array}$ \\
\hline Cicchillitti et $\mathrm{al}^{39}$ & Italy & $\mathrm{EC}$ & seRum & 59/NA & Level & RT-PCR & Diagnosis \\
\hline Dobrzycka et al ${ }^{40}$ & Poland & EC & Plasma & I09/NA & Level & PCR-RFLP & Diagnosis \\
\hline Vizza et $a^{41}$ & Italy & $\mathrm{EC}$ & Serum & 60/NA & Level & RT-PCR & Diagnosis \\
\hline Tanaka et $\mathrm{al}^{42}$ & Japan & $\mathrm{EC}$ & Plasma & $53 / 24$ & Level & RT-PCR & $\begin{array}{l}\text { Diagnosis/ } \\
\text { prognosis }\end{array}$ \\
\hline Hickey et $\mathrm{al}^{43}$ & $\begin{array}{l}\text { United } \\
\text { Kingdom }\end{array}$ & OC & Serum & 20/NA & Mutations, $\mathrm{LOH}$ and $\mathrm{MI}$ & PCR & Diagnosis \\
\hline Otsuka et $\mathrm{al}^{46}$ & Japan & OC & Plasma & $27 / N A$ & p53 mutation & PCR & $\begin{array}{l}\text { Diagnosis/ } \\
\text { prognosis }\end{array}$ \\
\hline Park et $\mathrm{al}^{47}$ & Korea & OC & Plasma & 4/NA & TP53 mutation & Digital PCR & Diagnosis \\
\hline Cohen et $\mathrm{al}^{49}$ & Australia & OC & Plasma & $32 / 32$ & Chromosomal instability & $\begin{array}{l}\text { Whole genome } \\
\text { NIPT platform }\end{array}$ & Diagnosis \\
\hline $\begin{array}{l}\text { Vanderstichele } \\
\text { et } \mathrm{al}^{50}\end{array}$ & Belgium & OC & Plasma & $57 / 11$ & Chromosomal instability & NGS & Diagnosis \\
\hline Phallen et $\mathrm{al}^{51}$ & USA & OC & Plasma & $42 / \mathrm{NA}$ & Somatic mutations & TEC-Seq & Diagnosis \\
\hline Farkkila et $\mathrm{al}^{52}$ & Finland & OC & Plasma & $35 / \mathrm{NA}$ & FOXL2 mutation & $d d P C R$ & $\begin{array}{l}\text { Diagnosis/ } \\
\text { prognosis }\end{array}$ \\
\hline Sun et $\mathrm{al}^{53}$ & China & $\mathrm{EC}$ & PBLs & $139 / 139$ & $\begin{array}{l}\text { mtDNA copy number } \\
\text { value }\end{array}$ & RT-PCR & Diagnosis \\
\hline $\begin{array}{l}\text { Giannopoulou } \\
\text { et } \mathrm{al}^{56}\end{array}$ & Greece & OC & Plasma & $59 / \mathrm{NA}$ & RASSFIA methylation & MSP technique & Diagnosis \\
\hline Zhang et $\mathrm{al}^{57}$ & China & OC & Serum & $87 / 115$ & $\begin{array}{l}\text { (APC, RASSFIA, CDHI, } \\
\text { RUNX3, TFPI2, SFRP5, } \\
\text { OPCML) methylation }\end{array}$ & MSP technique & Diagnosis \\
\hline Liggett et $\mathrm{al}^{58}$ & USA & OC & Plasma & $30 / 60$ & $\begin{array}{l}\text { (RASSFIA, CALCA, EP300, } \\
\text { BRCAI, CDKNIC, PGR- } \\
\text { PROX) methylation }\end{array}$ & MethDet 56 & Diagnosis \\
\hline Melnikov et $\mathrm{al}^{59}$ & USA & OC & Plasma & $33 / 33$ & $\begin{array}{l}\text { (BRCAI, HICI, PAX5, PGR, } \\
T H B S I) \text { methylation }\end{array}$ & MethDet 56 & Diagnosis \\
\hline $\begin{array}{l}\text { Widschwendter } \\
\text { et al }{ }^{60}\end{array}$ & UK & OC & Serum & $25 / 598$ & $\begin{array}{l}\text { (COL23Al, C2CD4D, } \\
\text { WNT6) methylation }\end{array}$ & NGS & $\begin{array}{l}\text { Diagnosis/ } \\
\text { prognosis }\end{array}$ \\
\hline
\end{tabular}

(Continued) 
Table I (Continued).

\begin{tabular}{|c|c|c|c|c|c|c|c|}
\hline References & Country & $\begin{array}{l}\text { Cancer } \\
\text { Type }\end{array}$ & Sources & $\begin{array}{l}\text { Cancerl } \\
\text { Control }\end{array}$ & Abnormalities & Methodology & $\begin{array}{l}\text { Clinical } \\
\text { Relevance }\end{array}$ \\
\hline $\mathrm{Li}$ et $\mathrm{al}^{61}$ & China & OC & Peripheral blood & $206 / 205$ & $\begin{array}{l}\text { Methylation at multiple } \\
\text { sites }\end{array}$ & NGS & Diagnosis \\
\hline$W u$ et $a^{62}$ & China & OC & Plasma & $47 / 24$ & RASSF2A methylation & MSP technique & Diagnosis \\
\hline Ibanez et $\mathrm{al}^{63}$ & USA & OC & Serum/plasma & 50/NA & $\begin{array}{l}(B R C A I, \text { RASSFIA }) \\
\text { methylation }\end{array}$ & MSP technique & Diagnosis \\
\hline Margolin et a ${ }^{67}$ & USA & $\mathrm{EC}$ & $\begin{array}{l}\text { A computational } \\
\text { simulation }\end{array}$ & $42 / 8$ & ZNFI54 methylation & NGS & Diagnosis \\
\hline Wimberger et $\mathrm{al}^{71}$ & Germany & OC & plasma & $62 / 28$ & Level & RT-PCR & prognosis \\
\hline Perkins et $\mathrm{al}^{72}$ & $\begin{array}{l}\text { United } \\
\text { Kingdom }\end{array}$ & OC & Plasma & $105 / 20$ & $\begin{array}{l}\text { Level/mutations in } 19 \\
\text { genes }\end{array}$ & NGS & Prognosis \\
\hline Steffensen et al ${ }^{73}$ & Denmark & OC & Plasma & I44/NA & Level & RT-PCR & Prognosis \\
\hline No et $\mathrm{al}^{74}$ & Korea & OC & Plasma & $36 / 16$ & $\begin{array}{l}(B 2 M, R A B 25, \\
C L D N 4, A B C F 2) \text { mutation }\end{array}$ & RT-PCR & Prognosis \\
\hline Kuhlmann et $\mathrm{al}^{75}$ & Germany & OC & Serum & $63 / 20$ & Level/LOH & $\begin{array}{l}\text { Fluorescence- } \\
\text { labeled PCR }\end{array}$ & Prognosis \\
\hline Swisher et al ${ }^{48}$ & USA & OC & Plasma/serum & I37/NA & p53 mutation & $\begin{array}{l}\text { DNA } \\
\text { sequencing }\end{array}$ & Prognosis \\
\hline $\begin{array}{l}\text { Giannopoulou } \\
\text { et } \mathrm{al}^{76}\end{array}$ & Greece & OC & Plasma & I29/NA & ESRI methylation & MSP technique & Prognosis \\
\hline Bolivar et $\mathrm{al}^{70}$ & USA & $\mathrm{EC}$ & Plasma & 48/NA & $\begin{array}{l}\text { (CTNNBI, KRAS, PTEN, } \\
\text { PIK3CA) mutation }\end{array}$ & NGS & Prognosis \\
\hline Harris et $\mathrm{al}^{77}$ & USA & OC & Plasma & 8/NA & Chromosomal junctions & $\begin{array}{l}\text { Quantitative } \\
\text { PCR }\end{array}$ & Prognosis \\
\hline Pereira et $\mathrm{al}^{78}$ & USA & $\begin{array}{l}\mathrm{OC} \text { and } \\
\mathrm{EC}\end{array}$ & Serum & $\begin{array}{l}220 C, 17 E C / \\
N A\end{array}$ & Level & Digital PCR & Prognosis \\
\hline Du et $\mathrm{al}^{79}$ & China & OC & Plasma & $2 \mathrm{I} / \mathrm{NA}$ & Mutations/CNV & NGS & Prognosis \\
\hline Martignetti et $\mathrm{al}^{80}$ & USA & OC & Plasma/serum & $\mathrm{I} / \mathrm{NA}$ & FGFR fusions & NGS/RT-PCR & Prognosis \\
\hline Choudhuri et al ${ }^{82}$ & India & OC & Plasma & I00/NA & Level & RT-PCR & $\begin{array}{l}\text { Treatment } \\
\text { response }\end{array}$ \\
\hline Capizzi et $\mathrm{al}^{83}$ & Italy & OC & Plasma & $22 / N A$ & Level & RT-PCR & $\begin{array}{l}\text { Treatment } \\
\text { response }\end{array}$ \\
\hline Arend et $\mathrm{al}^{84}$ & USA & OC & plasma & I4/NA & level & NGS & $\begin{array}{l}\text { Treatment } \\
\text { response }\end{array}$ \\
\hline Kamat et $\mathrm{al}^{69}$ & USA & $\begin{array}{l}O C \text { in } \\
\text { mice }\end{array}$ & Plasma & - & Level & RT-PCR & $\begin{array}{l}\text { Treatment } \\
\text { response }\end{array}$ \\
\hline Parkinson et al ${ }^{68}$ & $\begin{array}{l}\text { United } \\
\text { Kingdom }\end{array}$ & OC & Plasma & 40/NA & TP53 mutation & Digital PCR & $\begin{array}{l}\text { Treatment } \\
\text { response }\end{array}$ \\
\hline
\end{tabular}

(Continued) 
Table I (Continued).

\begin{tabular}{|c|c|c|c|c|c|c|c|}
\hline References & Country & $\begin{array}{l}\text { Cancer } \\
\text { Type }\end{array}$ & Sources & $\begin{array}{l}\text { Cancerl } \\
\text { Control }\end{array}$ & Abnormalities & Methodology & $\begin{array}{l}\text { Clinical } \\
\text { Relevance }\end{array}$ \\
\hline Gifford et $\mathrm{al}^{85}$ & $\begin{array}{l}\text { United } \\
\text { Kingdom }\end{array}$ & OC & Plasma & I38/NA & $h M L H I$ methylation & $\begin{array}{l}\text { Microsatellite } \\
\text { PCR }\end{array}$ & $\begin{array}{l}\text { Treatment } \\
\text { response }\end{array}$ \\
\hline Flanagan et a ${ }^{86}$ & $\begin{array}{l}\text { United } \\
\text { Kingdom }\end{array}$ & OC & Peripheral blood & $247 / N A$ & Methylation at $C_{P} G$ sites & NGS & $\begin{array}{l}\text { Treatment } \\
\text { response }\end{array}$ \\
\hline Matulonis et $\mathrm{al}^{90}$ & USA & OC & Plasma & 67/NA & $\begin{array}{l}\text { Mutations in components/ } \\
\text { modulators of the PI3K } \\
\text { pathway }\end{array}$ & $\begin{array}{l}\text { NGS/Sanger } \\
\text { sequencing }\end{array}$ & $\begin{array}{l}\text { Treatment } \\
\text { response }\end{array}$ \\
\hline Weigelt et al ${ }^{87}$ & USA & OC & Plasma & I9/NA & $B R C A$ reversion mutation & NGS & $\begin{array}{l}\text { Treatment } \\
\text { response }\end{array}$ \\
\hline Christie et al ${ }^{88}$ & Australia & OC & Plasma & 30/NA & $B R C A$ reversion mutation & NGS & $\begin{array}{l}\text { Treatment } \\
\text { response }\end{array}$ \\
\hline Lin et $\mathrm{al}^{89}$ & USA & OC & Plasma & 209/NA & $B R C A$ reversion mutation & NGS & $\begin{array}{l}\text { Treatment } \\
\text { response }\end{array}$ \\
\hline
\end{tabular}

Abbreviations: OC, ovarian cancer; EC, endometrial cancer; bDNA, branched DNA; PCR-RFLP, PCR-restriction fragment length polymorphism; LOH, loss of heterozygosity; MI, microsatellite instability; NGS, next-generation sequencing; mtDNA, mitochondrial DNA; ddPCR, digital droplet PCR; PBLs, peripheral blood leukocytes; MSP, methylation-specific PCR; CNV, copy number variation; NK, do not know.

\section{Genomic Alterations of cfDNA/ctDNA Ovarian Cancer}

Detection of molecular alterations in cfDNA/ctDNA dates back to 1999, when Hickey et al used PCR to detect loss of heterozygosity $(\mathrm{LOH})$ and microsatellite instability in $20 \mathrm{OC}$ patients. ${ }^{43}$ TP53 mutations were reported as the most common in OC, accounting for approximately $96 \%$ of the somatic mutations. ${ }^{44,45}$ Articles targeting TP53 mutations in cfDNA/ctDNA with different detection techniques have been published, implying their roles in OC management. ${ }^{46-48}$

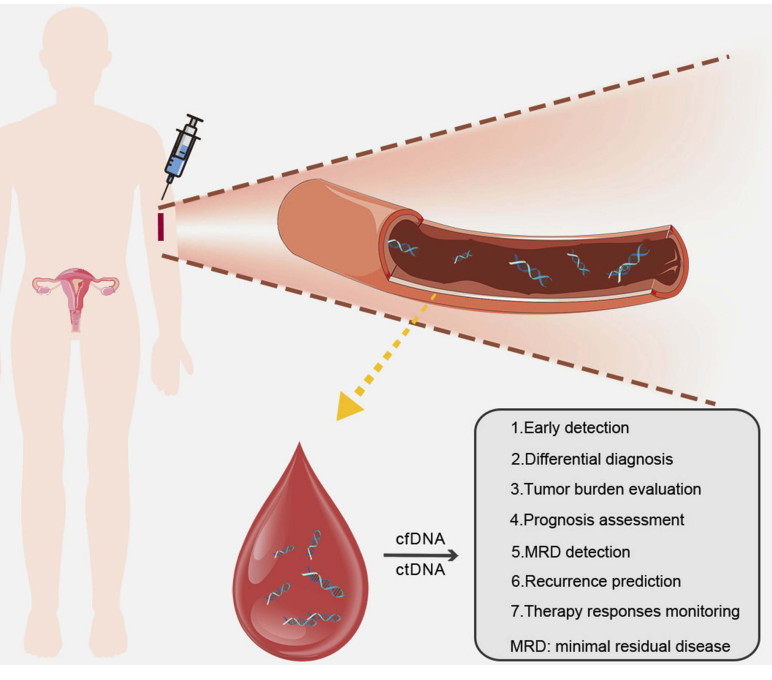

Figure I Applications of cfDNA/ctDNA in ovarian or endometrial cancer patients.
Researches centered on other genetic alterations or gene panels with several selected genes of cfDNA/ctDNA were also carried out. Cohen et al conducted a proof-of-concept study for subchromosomal with a low coverage sequencing approach called non-invasive prenatal testing platform, observing a relatively low sensitivity of $40.6 \%$, but a high specificity of $93.8 \% .{ }^{49}$ A recent study focused on the chromosomal instability of cfDNA included 68 patients presenting adnexal masses. In terms of the area under the curve (AUC), a much higher sensitivity over CA125 appeared, when the specificity was set to $99.6 \%{ }^{50}$ An ultrasensitive approach called TEC-Seq was applied to detect ctDNA alterations in different kinds of tumors based on a welldesigned combination of genes. Of the 42 enrolled OC patients, $71 \%$ were found with ctDNA alterations, and the fraction turned into $68 \%$ when researchers focused on earlystage patients. ${ }^{51}$ Farkkila et al developed a study to detect the FOXL2 mutation in ctDNA of adult granulosa cell tumor (AGCT) patients with ddPCR assay, revealing a sensitivity and specificity of $23 \%$ and $90 \%$, respectively. ${ }^{52}$

\section{Endometrial Cancer}

With regard to EC patients, Sun et al conducted a special research on mitochondrial DNA (mtDNA) copy number detection in peripheral blood leukocytes (PBLs) rather than serum or plasma. ${ }^{53}$ Alterations in mtDNA may lead to mitochondrial dysfunction, thus contributing to tumorigenesis. ${ }^{54}$ 
They reported that low mtDNA copy number indicated a more than five-fold increase in the risk of EC. ${ }^{53}$

\section{Epigenetic Changes of cfDNA/ctDNA}

Alteration of DNA methylation has been proven to be an early event of tumorigenesis, making the analysis of circulating DNA methylation patterns a potential method to detect $\mathrm{OC}$ and EC. ${ }^{55}$

\section{Ovarian Cancer}

Published studies applied similar research methods for OC, while focused on different genes. ${ }^{56-62}$ Ibanez et al developed a promoter hypermethylation analysis of 6-gene panel in the serum of OC patients (ranging from early to advanced-stage patients), observing a sensitivity of $82 \%$ and a specificity of $100 \% .{ }^{63}$ A 7 -gene panel study showed higher sensitivity and specificity $(85.3 \%$ and $90.5 \%$, respectively) of cfDNA than CA125 (56.1\% and $64.15 \%$, respectively) in stage I OC. ${ }^{57}$ There are similar studies published with different results of sensitivities and specificities, which may attribute to different markers they adopted. ${ }^{58,59}$ Although Widschwendter's group observed sensitivities of $41.4 \%$ and $82.8 \%$, and specificities of $90.7 \%$ and $87.1 \%$, respectively, for a three-DNAmethylation-serum-marker panel and CA125, they noticed that cfDNA can detect OC much earlier than the exact diagnosis. ${ }^{60}$ In addition, $\mathrm{Li}$ et al obtained a prediction accuracy of $77.3 \%$ in the included OC population for the six validated CPG sites. ${ }^{61}$ It is worth noticing that four of the studies mentioned above selected RASSF1A gene as one of the biomarkers. ${ }^{56,57,59,63} \mathrm{Wu}$ et al evaluated the methylation status of RASSF $2 A$, observing an aberrant rate of $51.1 \%$ in tissues and $36.2 \%$ in corresponding plasma samples. ${ }^{62}$ The $R A S S F$ gene family has been reported to play vital roles in tumorigenesis of various malignancies. ${ }^{64-66}$ Epigenetic alterations of $R A S S F$ gene family, especially RASSF $1 A$ and RASSF $2 A$ may be promising as a marker that warrants further investigations.

\section{Endometrial Cancer}

Margolin et al developed a study to detect the hypermethylation of the ZNF154 CpG island in five types of tumor, including $42 \mathrm{EC}$ patients. Apart from the tissue samples, a computational simulation of ctDNA ( $1 \%$ tumor DNA in $99 \%$ normal DNA) was also applied in their study, and an AUC of 0.79 was proved to show the best performance in endometrial tumors. ${ }^{67}$

\section{Tumor Burden Evaluation and Prognosis Assessment}

Analysis of cfDNA/ctDNA allows doctors to gain insight into tumor burden, thus providing references for subsequent treatment. Information on survival outcomes predicted by cfDNA/ctDNA could assist us in developing therapeutic projects and personal follow-up plans for cancer patients.

\section{Tumor Burden Evaluation \\ Ovarian Cancer}

A significant discrepancy of cfDNA levels between stage I-II and stage III-IV $(\mathrm{P}<0.01)$ was reported based on an analysis of 36 OC cases, ${ }^{34}$ and a strong relationship between ctDNA level and tumor volume was also documented in a group of high-grade serous ovarian carcinoma patients, ${ }^{68}$ suggesting the potential value of cfDNA/ ctDNA in evaluating tumor burden. A study in mice confirmed that elevated ctDNA levels indicated elevated tumor burden. ${ }^{69}$ In addition to quantification, specific genetic mutations can also reflect tumor burden. Larger median tumor size was observed in AGCT patients with FOXL2 ctDNA mutations by a research group. ${ }^{52}$

\section{Endometrial Cancer}

Relative researches about EC are rarely seen, but one has found that the appearance of plasma DNA mutations was remarkably correlated with primary tumor size. ${ }^{70}$

\section{Prognosis Assessment Ovarian Cancer}

Several studies drew similar conclusions on the prognostic role of cfDNA levels, that is, an increased cfDNA levels indicate a significant reduction in overall survival (OS) in OC patients. ${ }^{35,38,71-73}$ From the perspective of genetic changes, certain genes were verified to be useful to assess prognosis. No et al reported that $R A B 25$ levels in serum cfDNA were remarkably related to disease-free survival $(\mathrm{HR}=18.2,95 \% \mathrm{CI}=2.0-170.0)$ and $\mathrm{OS}(\mathrm{HR}=33.6,95 \%$ $\mathrm{CI}=1.8-634.8)$ of advanced-stage OC patients. ${ }^{74} \mathrm{LOH}$ proximal to $M 6 P / I G F 2 R$ locus (D6S1581) was found to be associated with OS $(\mathrm{P}=0.030)$ in another study. ${ }^{75}$ The level of $\mathrm{cfDNA}^{72}$ or presence of specific ctDNA mutation ${ }^{48}$ was even identified as an independent predictor of OS for OC patients. In addition, the presence of ESRI methylation in primary tumor samples was significantly correlated with better survival outcomes, though the correlation was not significant in plasma samples. ${ }^{76}$ 


\section{Endometrial Cancer}

Plasma DNA mutations in EC patients were found to be significantly related to deep myometrial invasion and lymphatic/vascular invasion, suggesting a possibly poorer survival outcome than those with only wildtype DNA. ${ }^{70}$

\section{Minimal Residual Disease (MRD) Detection and Recurrence Prediction}

Postoperative residual disease may occur in advanced OC and EC patients even under standard surgical procedures. As a potential source of relapse, it poses a serious threat to the patient's survival outcome. As aforementioned, despite emerging new treatment strategies, recurrences of $\mathrm{OC}$ and EC remain as urgent problems to be resolved. The evaluation of residual tumor burden and recurrence is thus important, and cfDNA/ctDNA may offer assistance.

\section{Ovarian Cancer}

Wimberger et al demonstrated that serum DNA levels of OC patients were significantly correlated with postoperative residual tumor load of $>1 \mathrm{~cm}(\mathrm{p}=0.0001)$ and a higher risk of relapse $(p=0.002){ }^{71}$ Similar relationship between preoperative cfDNA levels and residual tumor load $(p=0.017)$ was mentioned in another study. ${ }^{75}$ A research focusing on selected chromosomal junctions reported presence of ctDNA after surgery in patients with detectable disease, while no ctDNA in those without the disease. ${ }^{77}$

ctDNA may provide opportunities of timely treatment of recurrent lesions that were not detectable through imaging. One research revealed that ctDNA could make a diagnosis for relapsed OC cases 7 months earlier than CT scanning. ${ }^{78}$ In patients with recurrent $\mathrm{OC}$, the coincidence rates of TP53 and $B R C A 1$ in cfDNA and tumor tissue DNA were $76.2 \%$ and $95.24 \%$, respectively, which means that cfDNA/ctDNA could assist the monitoring of disease progression. ${ }^{79}$ Otsuka et al noticed in a follow-up survey that one patient with reemerging $p 53$ mutation after surgery died shortly after, while the other one with no $p 53$ mutation survived. ${ }^{46}$ An American study revealed a more sensitive and specific biomarker, the fibroblast growth factor receptor 2 (FGFR2) fusion ctDNA biomarker, to detect OC. In a series of 28 measurements during a 4-year follow-up of a specific patient, FGFR2 fusion better reflected the evolvement of the disease than CA125, especially the tumor recurrences. ${ }^{80}$

\section{Endometrial Cancer}

Levels of cfDNA were evaluated in a cohort of $25 \mathrm{EC}$ patients before and after operation, and 3 cases whose postoperative cfDNA levels did not decrease as expected relapsed during the follow up. ${ }^{41}$

\section{Therapy Responses Monitoring}

As the molecular mechanisms of tumors continue to unlock, different types of targeted drugs have been validated in clinical trials. Treatment resistance occurs commonly, possibly because of the genomic heterogeneity or tumor subclonal evolution under selection pressure. ${ }^{81}$ Real-time monitoring of therapeutic response is pivotal as it helps to understand the dynamic development of the disease. Detection of cfDNA/ctDNA may achieve the goal of screening out potential drug-resistant patients and instituting candidate-tailored therapeutic project to reduce the recurrence rate and improving survival rate.

\section{Ovarian Cancer}

Several studies, including a study of the OC mouse model, reported a decrease in cfDNA levels after ovarian cancer treatment, and some studies have shown that it is associated with post-therapy survival. ${ }^{69,82,83}$ On the other hand, significant changes in genetic variants of cfDNA were noticed after chemotherapy. ${ }^{84}$ In relapsed patients, a $>60 \%$ reduction in TP53 mutant allele fraction was reported as an independent predictor of time to progression after one cycle of chemotherapy. ${ }^{68}$ In one study, methylation changes of the hMLH1 gene in plasma DNA were detected (before chemotherapy and at relapse) in 138 patients with stage IC-IV OC who experienced a relapse. A significant $(\mathrm{P}<0.001)$ increase of the positive rate (from $12 \%$ to $33 \%$ ) in $h M L H 1$ methylation was observed, together with a poor OS. This study provided evidence to support the idea that the loss of DNA mismatch repair (MMR) might involve in the process of acquired drug resistance. ${ }^{85}$ Another study also documented changes in plasma DNA methylation in patients with OC who relapsed after platinum-based chemotherapy. ${ }^{86}$ The identification of chemotherapy responders and nonresponders was essential for the subsequent treatment plan, and the analysis of DNA-methylation-serum-marker panel will be useful. ${ }^{58}$

Recently, a couple of studies have been developed to explore the acquisition of $B R C A$ reversion mutations and their roles in drug resistance by analyzing cfDNA/ctDNA in OC patients who received platinum-based chemotherapies or PARP inhibitors. ${ }^{87-89}$ Detection of $B R C A$ reversion mutations in cfDNA/ctDNA has been proven to be useful to predict possible drug resistance and guide treatment strategies. 


\section{Endometrial Cancer}

Matulonis et al conducted a study to assess treatment response of PI3K inhibitor pilaralisib in advanced or recurrent EC cases. Different degrees of consistency were noticed between ctDNA and paired tumor tissue on the status of PIK3CA, KRAS, and BRAF genes. ${ }^{90}$

\section{Possible Applications of cfDNA/ctDNA in Specific Situations Utility of cfDNA/ctDNA in Fertility-Sparing Treatment}

Advanced techniques, including detection techniques of cfDNA/ctDNA, have improved the detection rate of earlystage disease. Choices of fertility-sparing approaches for gynecological cancer patients are receiving greater attention, since an increasing number of patients are diagnosed at productive age and desire to have children. Gynecological cancers have a negative impact on the sexuality and fertility of patients, increasing their stress level and reducing personal identity, which may pose a threat to the quality of their lives. $^{91}$

Most OC cases are diagnosed at an advanced stage, for whom cytoreduction remains optimal. However, fertilitysparing surgery is still recommended for selected patients by several society recommendations, with the premise of a comprehensive surgical staging. ${ }^{92,93}$

As for EC patients, total hysterectomy and bilateral salpingo-oophorectomy with or without surgical staging are regarded as the standard treatment. Fertility-sparing surgery is a choice for reproductive-aged patients with stage IA type I and G2 EC. ${ }^{94}$ Furthermore, previous studies have evaluated the accuracy of preoperative methods, such as magnetic resonance imaging (MRI), TVS and hysteroscopically directed biopsies, for predicting the nodal-spread risk of EC. ${ }^{95,96}$ They concluded that these preoperative mapping methods worked well with high accuracy, avoiding over- or under-treatment of EC patients, while more evidence in this field is still needed. Conservative treatment such as progestational agents has attracted widespread attention among premenopausal women who are eager to give birth and have achieved favorable outcomes in early-stage patients. ${ }^{97-100}$

Given the risk of recurrences, monitoring must be strengthened for patients receiving conservative treatment. Non-invasive detection of cfDNA/ctDNA provides a more convenient tool for tracking disease progression, which helps to assess treatment response. Nevertheless, no relative data have been published by now, and the application of cfDNA/ctDNA analysis in this field needs further investigations.

\section{Utility of cfDNA/ctDNA in the Management of Elderly Patients}

The incidence of cancer in elderly population is much higher than the young group. However, the management of elderly patients remains a challenge. In the clinical setting, treatment patterns of elderly patients with OC and $\mathrm{EC}$ often differ from younger patients, and are less aggressive, due to their seemingly fragile bodies. ${ }^{101,102}$ Studies supported that age itself was not a prognostic factor for survival outcome, and elderly patients could also receive standard treatments. ${ }^{102}$ The management of elderly OC or EC patients should be personalized according to the performance status of the patients, the extent of the disease and their life goals. ${ }^{102}$ The detection of cfDNA/ctDNA may act as an assistant examination during the whole course of the management, given its noninvasive nature.

\section{Detection of cfDNA/ctDNA in Non-Blood Fluids}

In addition to blood, cfDNA/ctDNA is also detectable in other body fluids, among which urine, peritoneal fluid and uterine lavage fluid were reported to be utilized in the management of OC or EC patients (Table 2). Compared to bloodstream, the concentration of ctDNA shed in nonblood fluids can be higher in some certain cancer types. ${ }^{103}$ However, a lack of relative researches and protocols, as well as rare experience in the exploration of these tests remain problems for non-blood-based liquid biopsy.

Several studies focused on tumor-specific genetic alterations of DNA extracted from peritoneal fluid samples of OC patients, receiving relatively high sensitivities in detection. ${ }^{43,48,104-106}$ In 2004, methylation of peritoneal DNA was first reported as an independent factor in OC survival. ${ }^{107}$ Shortly after, hypermethylation was detected in peritoneal fluid DNA with relatively high sensitivity and specificity, including 3 cytologically negative patients. ${ }^{63} \mathrm{Du}$ and his colleagues included urine samples into their study for genetic mutation analysis, identifying a detection rate of $86 \%{ }^{79}$ Nair et al conducted a study to detect endometrial driver mutations in uterine lavage in seven EC patients, of whom six were at early stage. ${ }^{108}$ In another similar study, specific mutations were identified in $80 \%(24 / 30)$ OC and $100 \%(5 / 5)$ EC patients. ${ }^{109}$ It has been confirmed that tumor 
Table 2 Studies with Analysis of cfDNA/ctDNA in Other Body Fluids of OC or EC Patients

\begin{tabular}{|c|c|c|c|c|c|c|c|}
\hline References & Country & $\begin{array}{l}\text { Cancer } \\
\text { Type }\end{array}$ & Fluid Type & $\begin{array}{l}\text { Number of } \\
\text { Samples }\end{array}$ & Abnormalities & Methodology & $\begin{array}{l}\text { Clinical } \\
\text { Relevance }\end{array}$ \\
\hline Hickey et $\mathrm{al}^{43}$ & $\begin{array}{l}\text { United } \\
\text { Kingdom }\end{array}$ & OC & Peritoneal fluid & 20 & Mutations, $\mathrm{LOH}$ and $\mathrm{MI}$ & PCR & Diagnosis \\
\hline Swisher et al ${ }^{48}$ & USA & OC & Peritoneal fluid & 30 & p53 mutation & $\begin{array}{l}\text { DNA } \\
\text { sequencing }\end{array}$ & Prognosis \\
\hline $\begin{array}{l}\text { Krimmel } \\
\text { et } \text { al }^{104}\end{array}$ & USA & OC & Peritoneal fluid & 37 & TP53 mutation & $\begin{array}{l}\text { Duplex } \\
\text { sequencing }\end{array}$ & Diagnosis \\
\hline Parrella et al ${ }^{105}$ & Italy & OC & Peritoneal fluid & 15 & $\begin{array}{l}\text { (p53,KRAS) mutation/ } \\
\mathrm{LOH}\end{array}$ & $\begin{array}{l}\text { DNA } \\
\text { sequencing }\end{array}$ & Diagnosis \\
\hline Barquin et al ${ }^{106}$ & Spain & OC & Peritoneal fluid & 10 & BRCA mutation & $\begin{array}{l}\text { DNA } \\
\text { sequencing }\end{array}$ & Prognosis \\
\hline Muller et al ${ }^{107}$ & Austria & OC & Peritoneal fluid & 61 & $\begin{array}{l}\text { methylation of } 15 \\
\text { selected genes }\end{array}$ & MethyLight & Prognosis \\
\hline $\mid$ Ibanez et $\mathrm{al}^{63}$ & USA & OC & Peritoneal fluid & 42 & $\begin{array}{l}(B R C A I, \text { RASSFIA }) \\
\text { methylation }\end{array}$ & MSP technique & Diagnosis \\
\hline Du et $\mathrm{al}^{79}$ & China & OC & $\begin{array}{l}\text { Urine and } \\
\text { ascites }\end{array}$ & 21 and 13 & Mutations/CNV & NGS & Prognosis \\
\hline Nair et al ${ }^{108}$ & USA & $\mathrm{EC}$ & $\begin{array}{l}\text { Uterine lavage } \\
\text { fluid }\end{array}$ & 107 & $\begin{array}{l}\text { Mutations of selected } \\
\text { genes }\end{array}$ & NGS & Diagnosis \\
\hline $\begin{array}{l}\text { Maritschnegg } \\
\text { et al }{ }^{109}\end{array}$ & Austria & $\begin{array}{l}\mathrm{OC} \text { and } \\
\mathrm{EC}\end{array}$ & $\begin{array}{l}\text { Uterine lavage } \\
\text { fluid }\end{array}$ & 30 and 5 & Somatic mutations & NGS & Diagnosis \\
\hline Kinde et al ${ }^{110}$ & USA & $\begin{array}{l}\mathrm{OC} \text { and } \\
\mathrm{EC}\end{array}$ & $\begin{array}{l}\text { Liquid-based Pap } \\
\text { smear }\end{array}$ & 22and 24 & Somatic mutations & NGS & Diagnosis \\
\hline Wang et al ${ }^{\prime \prime \prime}$ & USA & $\begin{array}{l}\mathrm{OC} \text { and } \\
\mathrm{EC}\end{array}$ & $\begin{array}{l}\text { Pap brush } \\
\text { samples }\end{array}$ & 245 and 382 & Somatic mutation & $\begin{array}{l}\text { Safe-sequencing } \\
\text { system }\end{array}$ & Diagnosis \\
\hline
\end{tabular}

Abbreviations: OC, ovarian cancer; EC, endometrial cancer; LOH, loss of heterozygosity; MI, microsatellite instability; MSP, methylation-specific PCR; CNV, copy number variation; NGS, next-generation sequencing; Pap, Papanicolaou.

DNA is detectable in detached cells from ovarian and endometrial malignancies collected at the cervix. ${ }^{110}$ Recently, genetic analysis of Papanicolaou (Pap) test using liquidbased methods rather than traditional Pap smear revealed potential advantages in early detection of $\mathrm{OC}$ and $\mathrm{EC}$ patients. $^{110,111}$

\section{Conclusion}

On June 1, 2016, cobas EGFR Mutation Test v2 was approved by the U. S. Food and Drug Administration (FDA) to identify patients with metastatic non-small cell lung cancer (NSCLC) appropriate for treatment with Tarceva $^{\circledR}$ (erlotinib). ${ }^{12}$ This test, focusing on the mutation of the epidermal growth factor receptor $(E G F R)$ gene in the cfDNA isolated from the blood samples of patients, is the first cfDNA/ctDNA test officially applied to clinical work. ${ }^{112}$ Currently, no cfDNA/ctDNA-related test has been approved by FDA in the field of OC and EC. Encouragingly, as mentioned above, published studies supported the feasibility of cfDNA/ctDNA's application in the interrogation of tumor genome profiles and real-time tracing of the tumor conditions in OC and EC patients. The analysis of levels, genetic changes and epigenetic alterations of cfDNA/ctDNA hold tremendous promise in a wide range of applications: cancer screening, tumor burden evaluation, prognosis assessment, MRD detection, recurrence surveillance and treatment monitoring. In addition, a large number of clinical trials exploring the role of cfDNA/ctDNA in the management of OC and EC are underway (for example, NCT03691012), which may provide us with strong evidence. 
It should be noted that well-defined preanalytical, analytical and postanalytical protocols are the prerequisites to obtain convincing results from large-scale clinical trials. Efforts are still needed to overcome challenges in detection techniques such as low amounts of cfDNA/ctDNA and high background signals. Combination of this new liquid biopsy method with other traditional methods may yield more satisfactory results. Accumulated evidence for survival benefits is required to integrate this novel diagnostic approach into the clinical scenario in the foreseeable future.

\section{Acknowledgments}

This study was funded by CAMS Youth Talent Award Project (No. 2018RC320006) and CAMS Innovation Fund for Medical Sciences (CIFMS; No. 2016-I2M-1-002).

\section{Disclosure}

The authors report no conflicts of interest in this work.

\section{References}

1. McGranahan N, Swanton C. Clonal heterogeneity and tumor evolution: past, present, and the future. Cell. 2017;168 (4):613-628. doi:10.1016/j.cell.2017.01.018

2. Cohen PA, Jhingran A, Oaknin A, Denny L. Cervical cancer. Lancet. 2019;393(10167):169-182. doi:10.1016/S0140-6736(18) 32470-X

3. Torre LA, Bray F, Siegel RL, Ferlay J, Lortet-Tieulent J, Jemal A. Global cancer statistics, 2012. CA Cancer J Clin. 2015;65 (2):87-108. doi:10.3322/caac.21262

4. Henderson JT, Webber EM, Sawaya GF. Screening for ovarian cancer: updated evidence report and systematic review for the US preventive services task force. JAMA. 2018;319(6):595-606. doi:10.1001/jama.2017.21421

5. Parmar MK, Ledermann JA, Colombo N, et al. Paclitaxel plus platinum-based chemotherapy versus conventional platinum-based chemotherapy in women with relapsed ovarian cancer: the ICON4/ AGO-OVAR-2.2 trial. Lancet. 2003;361(9375):2099-2106.

6. Bast RC Jr. CA 125 and the detection of recurrent ovarian cancer: a reasonably accurate biomarker for a difficult disease. Cancer. 2010;116(12):2850-2853. doi:10.1002/cncr.v116:12

7. Siegel RL, Miller KD, Jemal A. Cancer statistics, 2019. $C A$ Cancer J Clin. 2019;69(1):7-34. doi:10.3322/caac.21551

8. Yasa C, Dural O, Bastu E, Ugurlucan FG, Nehir A, Iyibozkurt AC. Evaluation of the diagnostic role of transvaginal ultrasound measurements of endometrial thickness to detect endometrial malignancy in asymptomatic postmenopausal women. Arch Gynecol Obstet. 2016;294(2):311-316. doi:10.1007/s00404-016-4054-5

9. Dijkhuizen FP, Mol BW, Brolmann HA, Heintz AP. The accuracy of endometrial sampling in the diagnosis of patients with endometrial carcinoma and hyperplasia: a meta-analysis. Cancer. 2000;89 (8):1765-1772. doi:10.1002/1097-0142(20001015)89:8<1765::AIDCNCR17>3.0.CO;2-F

10. Lianidou E, Pantel K. Liquid biopsies. Genes Chromosomes Cancer. 2019;58(4):219-232. doi:10.1002/gcc.v58.4

11. Jia S, Zhang R, Li Z, Li J. Clinical and biological significance of circulating tumor cells, circulating tumor DNA, and exosomes as biomarkers in colorectal cancer. Oncotarget. 2017;8(33): 55632-55645. doi:10.18632/oncotarget.v8i33
12. Cheng X, Zhang L, Chen Y, Qing C. Circulating cell-free DNA and circulating tumor cells, the "liquid biopsies" in ovarian cancer. J Ovarian Res. 2017;10(1):75. doi:10.1186/s13048-017-0369-5

13. Mandel $P$, Metais $P$. Les acides nucléiques du plasma sanguin chez l'homme. C R Seances Soc Biol Fil. 1948;142(3-4):241-243.

14. Leon SA, Shapiro B, Sklaroff DM, Yaros MJ. Free DNA in the serum of cancer patients and the effect of therapy. Cancer Res. 1977;37(3):646-650.

15. Vasioukhin V, Anker P, Maurice P, Lyautey J, Lederrey C, Stroun M. Point mutations of the N-ras gene in the blood plasma DNA of patients with myelodysplastic syndrome or acute myelogenous leukaemia. $\mathrm{Br} \quad J$ Haematol. 1994;86(4):774-779. doi:10.1111/j.1365-2141.1994.tb04828.x

16. Mouliere F, Thierry AR. The importance of examining the proportion of circulating DNA originating from tumor, microenvironment and normal cells in colorectal cancer patients. Expert Opin Biol Ther. 2012;12(Suppl 1):S209-S215. doi:10.1517/14712 598.2012 .688023

17. Jahr S, Hentze H, Englisch S, et al. DNA fragments in the blood plasma of cancer patients: quantitations and evidence for their origin from apoptotic and necrotic cells. Cancer Res. 2001;61 (4):1659-1665.

18. Jiang P, Chan CW, Chan KC, et al. Lengthening and shortening of plasma DNA in hepatocellular carcinoma patients. Proc Natl Acad Sci U S A. 2015;112(11):E1317-E1325. doi:10.1073/pnas. 1500076112

19. Underhill HR, Kitzman JO, Hellwig S, et al. Fragment length of circulating tumor DNA. PLoS Genet. 2016;12(7):e1006162. doi:10.1371/journal.pgen.1006162

20. Bettegowda C, Sausen M, Leary RJ, et al. Detection of circulating tumor DNA in early- and late-stage human malignancies. Sci Transl Med. 2014;6(224):224ra224. doi:10.1126/scitranslmed. 3007094

21. Tug S, Helmig S, Deichmann ER, et al. Exercise-induced increases in cell free DNA in human plasma originate predominantly from cells of the haematopoietic lineage. Exerc Immunol Rev. 2015;21:164-173.

22. Pandoh PK, Corbett RD, McDonald $\mathrm{H}$, et al. A high-throughput protocol for isolating cell-free circulating tumor DNA from peripheral blood. Biotechniques. 2019;66(2):85-92. doi:10.2144/btn2018-0148

23. Fettke H, Kwan EM, Azad AA. Cell-free DNA in cancer: current insights. Cell Oncol (Dordr). 2019;42(1):13-28. doi:10.1007/ s13402-018-0413-5

24. Franczak C, Filhine-Tresarrieu P, Gilson P, Merlin JL, Au L, Harle A. Technical considerations for circulating tumor DNA detection in oncology. Expert Rev Mol Diagn. 2019;19 (2):121-135. doi:10.1080/14737159.2019.1568873

25. Diehl F, Schmidt K, Choti MA, et al. Circulating mutant DNA to assess tumor dynamics. Nat Med. 2008;14(9):985-990. doi:10.1 038/nm. 1789

26. Medina Diaz I, Nocon A, Mehnert DH, Fredebohm J, Diehl F, Holtrup F. Performance of streck cfDNA blood collection tubes for liquid biopsy testing. PLoS One. 2016;11(11):e0166354. doi:10.1371/journal.pone.0166354

27. Lu JL, Liang ZY. Circulating free DNA in the era of precision oncology: pre- and post-analytical concerns. Chronic Dis Transl Med. 2016;2(4):223-230. doi:10.1016/j.cdtm.2016.12.001

28. Haselmann V, Ahmad-Nejad P, Geilenkeuser WJ, et al. Results of the first external quality assessment scheme (EQA) for isolation and analysis of circulating tumour DNA (ctDNA). Clin Chem Lab Med. 2018;56(2):220-228. doi:10.1515/cclm-2017-0283

29. Forshew T, Murtaza M, Parkinson C, et al. Noninvasive identification and monitoring of cancer mutations by targeted deep sequencing of plasma DNA. Sci Transl Med. 2012;4 (136):136ra168. doi:10.1126/scitranslmed.3003726 
30. Buono G, Gerratana L, Bulfoni M, et al. Circulating tumor DNA analysis in breast cancer: is it ready for prime-time? Cancer Treat Rev. 2019;73:73-83. doi:10.1016/j.ctrv.2019.01.004

31. Lise BA, Ostrup O. Toward liquid biopsies in cancer treatment: application of circulating tumor DNA. APMIS. 2019;127:329-336.

32. Butler TM, Johnson-Camacho K, Peto M, et al. Exome sequencing of cell-free DNA from metastatic cancer patients identifies clinically actionable mutations distinct from primary disease. PLoS One. 2015;10(8):e0136407. doi:10.1371/journal.pone.0136407

33. Mouliere F, Chandrananda D, Piskorz AM, et al. Enhanced detection of circulating tumor DNA by fragment size analysis. Sci Transl Med. 2018;10(466):eaat4921. doi:10.1126/scitranslmed. aat4921

34. Shao X, He Y, Ji M, et al. Quantitative analysis of cell-free DNA in ovarian cancer. Oncol Lett. 2015;10(6):3478-3482. doi:10. 3892/ol.2015.3771

35. Kamat AA, Baldwin M, Urbauer D, et al. Plasma cell-free DNA in ovarian cancer: an independent prognostic biomarker. Cancer. 2010;116(8):1918-1925. doi:10.1002/cncr.v116:8

36. Kamat AA, Sood AK, Dang D, Gershenson DM, Simpson JL, Bischoff FZ. Quantification of total plasma cell-free DNA in ovarian cancer using real-time PCR. Ann $N$ Y Acad Sci. 2006;1075:230-234. doi:10.1196/annals.1368.031

37. Zachariah RR, Schmid S, Buerki N, Radpour R, Holzgreve W, Zhong X. Levels of circulating cell-free nuclear and mitochondrial DNA in benign and malignant ovarian tumors. Obstet Gynecol. 2008;112(4):843-850. doi:10.1097/AOG.0b013e31818 $67 \mathrm{bc} 0$

38. Dobrzycka B, Terlikowski SJ, Kinalski M, Kowalczuk O, Niklinska W, Chyczewski L. Circulating free DNA and p53 antibodies in plasma of patients with ovarian epithelial cancers. Ann Oncol. 2011;22(5):1133-1140. doi:10.1093/annonc/mdq584

39. Cicchillitti L, Corrado G, De Angeli M, et al. Circulating cell-free DNA content as blood based biomarker in endometrial cancer. Oncotarget. 2017;8(70):115230-115243. doi:10.18632/oncotarget.v8i70

40. Dobrzycka B, Terlikowski SJ, Mazurek A, et al. Circulating free DNA, p53 antibody and mutations of KRAS gene in endometrial cancer. Int $J$ Cancer. 2010;127(3):612-621. doi:10.1002/ijc. v127:3

41. Vizza E, Corrado G, De Angeli M, et al. Serum DNA integrity index as a potential molecular biomarker in endometrial cancer. J Exp Clin Cancer Res. 2018;37(1):16. doi:10.1186/s13046-0180688-4

42. Tanaka H, Tsuda H, Nishimura $\mathrm{S}$, et al. Role of circulating free alu DNA in endometrial cancer. Int J Gynecol Cancer. 2012;22 (1):82-86. doi:10.1097/IGC.0b013e3182328c94

43. Hickey KP, Boyle KP, Jepps HM, Andrew AC, Buxton EJ, Burns PA. Molecular detection of tumour DNA in serum and peritoneal fluid from ovarian cancer patients. $\mathrm{Br} J$ Cancer. 1999;80(11):1803-1808. doi:10.1038/sj.bjc.6690601

44. Rivlin N, Brosh R, Oren M, Rotter V. Mutations in the p53 tumor suppressor gene: important milestones at the various steps of tumorigenesis. Genes Cancer. 2011;2(4):466-474. doi:10.1177/ 1947601911408889

45. Cancer Genome Atlas Research N. Integrated genomic analyses of ovarian carcinoma. Nature. 2011;474(7353):609-615. doi:10.1038/nature10166

46. Otsuka J, Okuda T, Sekizawa A, et al. Detection of p53 mutations in the plasma DNA of patients with ovarian cancer. Int J Gynecol Cancer. 2004;14(3):459-464. doi:10.1111/ijg.2004.14.issue-3

47. Park YR, Kim YM, Lee SW, et al. Optimization to detect TP53 mutations in circulating cell-free tumor DNA from patients with serous epithelial ovarian cancer. Obstet Gynecol Sci. 2018;61 (3):328-336. doi:10.5468/ogs.2018.61.3.328
48. Swisher EM, Wollan M, Mahtani SM, et al. Tumor-specific p53 sequences in blood and peritoneal fluid of women with epithelial ovarian cancer. Am J Obstet Gynecol. 2005;193(3 Pt 1):662-667. doi:10.1016/j.ajog.2005.01.054

49. Cohen PA, Flowers N, Tong S, Hannan N, Pertile MD, Hui L. Abnormal plasma DNA profiles in early ovarian cancer using a non-invasive prenatal testing platform: implications for cancer screening. BMC Med. 2016;14(1):126. doi:10.1186/s12916-0160667-6

50. Vanderstichele A, Busschaert P, Smeets D, et al. Chromosomal instability in cell-free DNA as a highly specific biomarker for detection of ovarian cancer in women with adnexal masses. Clin Cancer Res. 2017;23(9):2223-2231. doi:10.1158/1078-0432. CCR-16-1078

51. Phallen J, Sausen M, Adleff V, et al. Direct detection of early-stage cancers using circulating tumor DNA. Sci Transl Med. 2017;9(403). doi:10.1126/scitranslmed.aan2415

52. Farkkila A, McConechy MK, Yang W, et al. FOXL2 402C $>$ G mutation can be identified in the circulating tumor DNA of patients with adult-type granulosa cell tumor. J Mol Diagn. 2017;19(1):126-136. doi:10.1016/j.jmoldx.2016.08.005

53. Sun Y, Zhang L, Ho SS, Wu X, Gu J. Lower mitochondrial DNA copy number in peripheral blood leukocytes increases the risk of endometrial cancer. Mol Carcinog. 2016;55(6):1111-1117. doi:10.1002/mc.v55.6

54. Clay Montier LL, Deng JJ, Bai Y. Number matters: control of mammalian mitochondrial DNA copy number. J Genet Genomics. 2009;36(3):125-131. doi:10.1016/S1673-8527(08)60099-5

55. Li L, Li C, Mao H, et al. Epigenetic inactivation of the $\mathrm{CpG}$ demethylase TET1 as a DNA methylation feedback loop in human cancers. Sci Rep. 2016;6:26591. doi:10.1038/srep26591

56. Giannopoulou L, Chebouti I, Pavlakis K, Kasimir-Bauer S, Lianidou ES. RASSF1A promoter methylation in high-grade serous ovarian cancer: a direct comparison study in primary tumors, adjacent morphologically tumor cell-free tissues and paired circulating tumor DNA. Oncotarget. 2017;8(13):21429-21443. doi:10.18632/oncotarget.v8i13

57. Zhang Q, Hu G, Yang Q, et al. A multiplex methylation-specific PCR assay for the detection of early-stage ovarian cancer using cell-free serum DNA. Gynecol Oncol. 2013;130(1):132-139. doi:10.1016/j.ygyno.2013.04.048

58. Liggett TE, Melnikov A, Yi Q, et al. Distinctive DNA methylation patterns of cell-free plasma DNA in women with malignant ovarian tumors. Gynecol Oncol. 2011;120(1):113-120. doi:10.10 16/j.ygyno.2010.09.019

59. Melnikov A, Scholtens D, Godwin A, Levenson V. Differential methylation profile of ovarian cancer in tissues and plasma. $J \mathrm{Mol}$ Diagn. 2009;11(1):60-65. doi:10.2353/jmoldx.2009.080072

60. Widschwendter M, Zikan M, Wahl B, et al. The potential of circulating tumor DNA methylation analysis for the early detection and management of ovarian cancer. Genome Med. 2017;9 (1):116. doi:10.1186/s13073-017-0500-7

61. Li L, Zheng H, Huang Y, et al. DNA methylation signatures and coagulation factors in the peripheral blood leucocytes of epithelial ovarian cancer. Carcinogenesis. 2017;38(8):797-805. doi:10.1 093/carcin/bgx057

62. Wu Y, Zhang X, Lin L, Ma XP, Ma YC, Liu PS. Aberrant methylation of RASSF2A in tumors and plasma of patients with epithelial ovarian cancer. Asian Pac J Cancer Prev. 2014;15 (3):1171-1176. doi:10.7314/APJCP.2014.15.3.1171

63. Ibanez de Caceres I, Battagli C, Esteller M, et al. Tumor cell-specific BRCA1 and RASSF1A hypermethylation in serum, plasma, and peritoneal fluid from ovarian cancer patients. Cancer Res. 2004;64(18):6476-6481. doi:10.1158/0008-5472.CAN-041529 
64. Iwasa H, Hossain S, Hata Y. Tumor suppressor C-RASSF proteins. Cell Mol Life Sci. 2018;75(10):1773-1787. doi:10.1007/s00018-018-2756-5

65. Fernandes MS, Carneiro F, Oliveira C, Seruca R. Colorectal cancer and RASSF family - a special emphasis on RASSF1A. Int $J$ Cancer. 2013;132(2):251-258. doi:10.1002/ijc.27696

66. Schmidt ML, Hobbing KR, Donninger H, Clark GJ. RASSF1A deficiency enhances RAS-driven lung tumorigenesis. Cancer Res. 2018;78(10):2614-2623. doi:10.1158/0008-5472.CAN-17-2466

67. Margolin G, Petrykowska HM, Jameel N, Bell DW, Young AC, Elnitski L. Robust detection of DNA hypermethylation of ZNF154 as a pan-cancer locus with in silico modeling for blood-based diagnostic development. J Mol Diagn. 2016;18 (2):283-298. doi:10.1016/j.jmoldx.2015.11.004

68. Parkinson CA, Gale D, Piskorz AM, et al. Exploratory analysis of TP53 mutations in circulating tumour DNA as biomarkers of treatment response for patients with relapsed high-grade serous ovarian carcinoma: a retrospective study. PLoS Med. 2016;13 (12):e1002198. doi:10.1371/journal.pmed.1002198

69. Kamat AA, Bischoff FZ, Dang D, et al. Circulating cell-free DNA: a novel biomarker for response to therapy in ovarian carcinoma. Cancer Biol Ther. 2006;5(10):1369-1374. doi:10.4161/cbt.5.10.3240

70. Bolivar AM, Luthra R, Mehrotra $\mathrm{M}$, et al. Targeted next-generation sequencing of endometrial cancer and matched circulating tumor DNA: identification of plasma-based, tumor-associated mutations in early stage patients. Modern Pathol. 2019;32(3):405-414. doi:10.1038/s41379-018-0158-8

71. Wimberger P, Roth C, Pantel K, Kasimir-Bauer S, Kimmig R, Schwarzenbach H. Impact of platinum-based chemotherapy on circulating nucleic acid levels, protease activities in blood and disseminated tumor cells in bone marrow of ovarian cancer patients. Int J Cancer. 2011;128(11):2572-2580. doi:10.1002/ijc.v128.11

72. Perkins G, Yap TA, Pope L, et al. Multi-purpose utility of circulating plasma DNA testing in patients with advanced cancers. PLoS One. 2012;7(11):e47020. doi:10.1371/journal.pone.004 7020

73. Steffensen KD, Madsen CV, Andersen RF, Waldstrom M, Adimi P, Jakobsen A. Prognostic importance of cell-free DNA in chemotherapy resistant ovarian cancer treated with bevacizumab. Eur J Cancer. 2014;50(15):2611-2618. doi:10.101 6/j.ejca.2014.06.022

74. No JH, Kim K, Park KH, Kim YB. Cell-free DNA level as a prognostic biomarker for epithelial ovarian cancer. Anticancer Res. 2012;32(8):3467-3471.

75. Kuhlmann JD, Schwarzenbach H, Wimberger P, Poetsch M, Kimmig R, Kasimir-Bauer S. $\mathrm{LOH}$ at $6 \mathrm{q}$ and $10 \mathrm{q}$ in fractionated circulating DNA of ovarian cancer patients is predictive for tumor cell spread and overall survival. BMC Cancer. 2012;12:325. doi:10.1186/1471-2407-12-325

76. Giannopoulou L, Mastoraki S, Buderath P, et al. ESR1 methylation in primary tumors and paired circulating tumor DNA of patients with high-grade serous ovarian cancer. Gynecol Oncol. 2018;150(2):355-360. doi:10.1016/j.ygyno.2018.05.026

77. Harris FR, Kovtun IV, Smadbeck J, et al. Quantification of somatic chromosomal rearrangements in circulating cell-free DNA from ovarian cancers. Sci Rep. 2016;6:29831. doi:10.103 8/srep29831

78. Pereira E, Camacho-Vanegas O, Anand S, et al. Personalized circulating tumor DNA biomarkers dynamically predict treatment response and survival in gynecologic cancers. PLoS One. 2015;10 (12):e0145754. doi:10.1371/journal.pone.0145754

79. Du ZH, Bi FF, Wang L, Yang Q. Next-generation sequencing unravels extensive genetic alteration in recurrent ovarian cancer and unique genetic changes in drug-resistant recurrent ovarian cancer. Mol Genet Genomic Med. 2018. doi:10.1002/mgg3.414
80. Martignetti JA, Camacho-Vanegas O, Priedigkeit $\mathrm{N}$, et al Personalized ovarian cancer disease surveillance and detection of candidate therapeutic drug target in circulating tumor DNA. Neoplasia. 2014;16(1):97-103. doi:10.1593/neo.131900

81. Rojas V, Hirshfield KM, Ganesan S, Rodriguez-Rodriguez L. Molecular characterization of epithelial ovarian cancer: implications for diagnosis and treatment. Int $J$ Mol Sci. 2016;17 (12):2113. doi:10.3390/ijms17122113

82. Choudhuri S, Sharma C, Banerjee A, Kumar S, Kumar L, Singh N A repertoire of biomarkers helps in detection and assessment of therapeutic response in epithelial ovarian cancer. Mol Cell Biochem. 2014;386(1-2):259-269. doi:10.1007/s11010-013-1863-8

83. Capizzi E, Gabusi E, Grigioni AD, et al. Quantification of free plasma DNA before and after chemotherapy in patients with advanced epithelial ovarian cancer. Diagn Mol Pathol. 2008;17 (1):34-38. doi:10.1097/PDM.0b013e3181359e1f

84. Arend RC, Londono AI, Montgomery AM, et al. Molecular response to neoadjuvant chemotherapy in high-grade serous ovarian carcinoma. Mol Cancer Res. 2018;16(5):813-824. doi:10.1158/1541-7786.MCR-17-0594

85. Gifford G, Paul J, Vasey PA, Kaye SB, Brown R. The acquisition of hMLH1 methylation in plasma DNA after chemotherapy predicts poor survival for ovarian cancer patients. Clin Cancer Res. 2004;10(13):4420-4426. doi:10.1158/1078-0432.CCR-03-0732

86. Flanagan JM, Wilson A, Koo C, et al. Platinum-based chemotherapy induces methylation changes in blood DNA associated with overall survival in patients with ovarian cancer. Clin Cancer Res. 2017;23(9):2213-2222. doi:10.1158/1078-0432.CCR-16-1754

87. Weigelt B, Comino-Mendez I, de Bruijn I, et al. Diverse BRCA1 and BRCA2 reversion mutations in circulating cell-free DNA of therapy-resistant breast or ovarian cancer. Clin Cancer Res. 2017;23(21):6708-6720. doi:10.1158/1078-0432.CCR-17-0544

88. Christie EL, Fereday S, Doig K, Pattnaik S, Dawson SJ, Bowtell DDL. Reversion of BRCA1/2 germline mutations detected in circulating tumor DNA from patients with high-grade serous ovarian cancer. J Clin Oncol. 2017;35 (12):1274-1280. doi:10.1200/JCO.2016.70.4627

89. Lin KK, Harrell MI, Oza AM, et al. BRCA reversion mutations in circulating tumor DNA predict primary and acquired resistance to the PARP inhibitor rucaparib in high-grade ovarian carcinoma. Cancer Discov. 2019;9(2):210-219. doi:10.1158/2159-8290.CD-18-0715

90. Matulonis U, Vergote I, Backes F, et al. Phase II study of the PI3K inhibitor pilaralisib (SAR245408; XL147) in patients with advanced or recurrent endometrial carcinoma. Gynecol Oncol. 2015;136(2):246-253. doi:10.1016/j.ygyno.2014.12.019

91. La Rosa VL, Shah M, Kahramanoglu I, et al. Quality of life and fertility preservation counseling for women with gynecological cancer: an integrated psychological and clinical perspective. J Psychosom Obstet Gynaecol. 2019;1-7. doi:10.1080/0167482X.2019.1648424

92. Calle EE, Kaaks R. Overweight, obesity and cancer: epidemiological evidence and proposed mechanisms. Nat Rev Cancer. 2004;4(8):579-591. doi:10.1038/nrc1408

93. Ledermann JA, Raja FA, Fotopoulou C, et al. Newly diagnosed and relapsed epithelial ovarian carcinoma: ESMO clinical practice guidelines for diagnosis, treatment and follow-up. Ann Oncol. 2013;24(Suppl 6):vi24-vi32. doi:10.1093/annonc/mdt333

94. Vitale SG, Rossetti D, Tropea A, Biondi A, Lagana AS. Fertility sparing surgery for stage IA type I and G2 endometrial cancer in reproductive-aged patients: evidence-based approach and future perspectives. Updates Surg. 2017;69(1):29-34. doi:10.1007/ s13304-017-0419-y

95. Cignini P, Vitale SG, Lagana AS, Biondi A, La Rosa VL, Cutillo G. Preoperative work-up for definition of lymph node risk involvement in early stage endometrial cancer: 5-year follow-up. Updates Surg. 2017;69(1):75-82. doi:10.1007/s133 04-017-0418-Z 
96. Ortoft G, Dueholm M, Mathiesen O, et al. Preoperative staging of endometrial cancer using TVS, MRI, and hysteroscopy. Acta Obstet Gynecol Scand. 2013;92(5):536-545. doi:10.1111/ aogs.2013.92.issue-5

97. Pronin SM, Novikova OV, Andreeva JY, Novikova EG. Fertilitysparing treatment of early endometrial cancer and complex atypical hyperplasia in young women of childbearing potential. Int J Gynecol Cancer. 2015;25(6):1010-1014. doi:10.1097/ IGC.0000000000000467

98. Pal N, Broaddus RR, Urbauer DL, et al. Treatment of low-risk endometrial cancer and complex atypical hyperplasia with the levonorgestrel-releasing intrauterine device. Obstet Gynecol. 2018;131(1):109-116. doi:10.1097/AOG.0000000000002390

99. Janda M, McGrath S, Obermair A. Challenges and controversies in the conservative management of uterine and ovarian cancer. Best Pract Res Clin Obstet Gynaecol. 2019;55:93-108. doi:10.1016/j.bpobgyn.2018.08.004

100. Greenwald ZR, Huang LN, Wissing MD, Franco EL, Gotlieb WH. Does hormonal therapy for fertility preservation affect the survival of young women with early-stage endometrial cancer? Cancer. 2017;123(9):1545-1554. doi:10.1002/cncr. v123.9

101. Schuurman MS, Kruitwagen R, Portielje JEA, Roes EM, Lemmens V, van der Aa MA. Treatment and outcome of elderly patients with advanced stage ovarian cancer: a nationwide analysis. Gynecol Oncol. 2018;149(2):270-274. doi:10.1016/j. ygyno.2018.02.017

102. Vitale SG, Capriglione S, Zito G, et al. Management of endometrial, ovarian and cervical cancer in the elderly: current approach to a challenging condition. Arch Gynecol Obstet. 2019;299 (2):299-315. doi:10.1007/s00404-018-5006-Z

103. Ponti G, Manfredini M, Tomasi A. Non-blood sources of cell-free DNA for cancer molecular profiling in clinical pathology and oncology. Crit Rev Oncol Hematol. 2019;141:36-42. doi:10.10 16/j.critrevonc.2019.06.005
104. Krimmel JD, Schmitt MW, Harrell MI, et al. Ultra-deep sequencing detects ovarian cancer cells in peritoneal fluid and reveals somatic TP53 mutations in noncancerous tissues. Proc Natl Acad Sci US A. 2016;113(21):6005-6010. doi:10.1073/pnas.1601311 113

105. Parrella P, Zangen R, Sidransky D, Nicol T. Molecular analysis of peritoneal fluid in ovarian cancer patients. Modern Pathol. 2003;16(7):636-640. doi:10.1097/01.MP.0000076979.28106.ED

106. Barquin M, Maximiano C, Perez-Barrios C, et al. Peritoneal washing is an adequate source for somatic BRCA1/2 mutation testing in ovarian malignancies. Pathol Res Pract. 2019;215 (2):392-394. doi:10.1016/j.prp.2018.10.028

107. Muller HM, Millinger S, Fiegl H, et al. Analysis of methylated genes in peritoneal fluids of ovarian cancer patients: a new prognostic tool. Clin Chem. 2004;50(11):2171-2173.

108. Nair N, Camacho-Vanegas O, Rykunov D, et al. Genomic analysis of uterine lavage fluid detects early endometrial cancers and reveals a prevalent landscape of driver mutations in women without histopathologic evidence of cancer: a prospective cross-sectional study. PLoS Med. 2016;13(12):e1002206. doi:10.1371/journal.pmed.1002206

109. Maritschnegg E, Wang Y, Pecha N, et al. Lavage of the uterine cavity for molecular detection of mullerian duct carcinomas: a proof-of-concept study. J Clin Oncol. 2015;33(36):4293-4300. doi:10.1200/JCO.2015.61.3083

110. Kinde I, Bettegowda C, Wang Y, et al. Evaluation of DNA from the Papanicolaou test to detect ovarian and endometrial cancers. Sci Transl Med. 2013;5(167):167ra164. doi:10.1126/scitranslmed. 3004952

111. Wang Y, Li L, Douville C, et al. Evaluation of liquid from the Papanicolaou test and other liquid biopsies for the detection of endometrial and ovarian cancers. Sci Transl Med. 2018;10(433). doi:10.1126/scitranslmed.aap8793

112. Kwapisz D. The first liquid biopsy test approved. Is it a new era of mutation testing for non-small cell lung cancer? Ann Transl Med. 2017;5(3):46. doi:10.21037/atm

\section{Publish your work in this journal}

OncoTargets and Therapy is an international, peer-reviewed, open access journal focusing on the pathological basis of all cancers, potential targets for therapy and treatment protocols employed to improve the management of cancer patients. The journal also focuses on the impact of management programs and new therapeutic agents and protocols on patient perspectives such as quality of life, adherence and satisfaction. The manuscript management system is completely online and includes a very quick and fair peer-review system, which is all easy to use. Visit http://www.dovepress.com/ testimonials.php to read real quotes from published authors. 